\title{
Marinomonas ostreistagni sp. nov., isolated from a pearl-oyster culture pond in Sanya, Hainan Province, China
}

Correspondence

Ken W. K. Lau

sslwk@ust.hk

\author{
Ken W. K. Lau, ${ }^{1}$ Jianping Ren, ${ }^{1}$ Natalie L. M. Wai, ${ }^{2}$ Simon C. L. Lau, ${ }^{1}$ \\ Pei-Yuan Qian, ${ }^{1}$ Po-Keung Wong ${ }^{2}$ and Madeline $\mathrm{Wu}^{1}$
${ }^{1}$ Department of Biology, The Hong Kong University of Science and Technology, Clear Water Bay, Kowloon, Hong Kong, SAR, P. R. China
${ }^{2}$ Department of Biology, The Chinese University of Hong Kong, Shatin, NT, Hong Kong, SAR, P. R. China

\begin{abstract}
A Gram-negative, aerobic, halophilic, neutrophilic, rod-shaped, non-pigmented, polar-flagellated bacterium, UST010306-043 ${ }^{\top}$, was isolated from a pearl-oyster culture pond in Sanya, Hainan Province, China in January 2001. This marine bacterium had an optimum temperature for growth of between 33 and $37^{\circ} \mathrm{C}$. On the basis of $16 \mathrm{~S}$ rRNA gene sequence analysis, the strain was closely related to Marinomonas aquimarina and Marinomonas communis, with $97 \cdot 5-97 \cdot 7$ and $97 \cdot 1 \%$ sequence similarity, respectively. Levels of DNA-DNA relatedness to the type strains of these species were well below $70 \%$. Analyses of phylogenetic, phenotypic and chemotaxomonic characteristics showed that strain UST010306-043 ${ }^{\top}$ was distinct from currently established Marinomonas species. A novel species with the name Marinomonas ostreistagni sp. nov. is proposed to accommodate this bacterium, with strain UST010306-043 ${ }^{\top}$ (=JCM $13672^{\top}=\mathrm{NRRL}$ $\left.\mathrm{B}-41433^{\top}\right)$ as the type strain.
\end{abstract}

Van Landschoot \& De Ley (1983) showed that, based on rRNA gene sequences, the genus Alteromonas (Baumann et al., 1972) was composed of four distinct branches and reclassified the branch containing Alteromonas vaga and Alteromonas communis as the genus Marinomonas. At the time of writing, the genus comprises eight species with validly published names: Marinomonas vaga, Marinomonas communis (Baumann et al., 1972; Van Landschoot \& De Ley, 1983), Marinomonas mediterranea (Solano \& SanchezAmat, 1999), Marinomonas primoryensis (Romanenko et al., 2003), Marinomonas pontica (Ivanova et al., 2005), Marinomonas ushuaiensis (Prabagaran et al., 2005), Marinomonas aquimarina (Macián et al., 2005) and Marinomonas dokdonensis (Yoon et al., 2005).

In this study, we report a novel strain, UST010306-043 ${ }^{\mathrm{T}}$, which was isolated from a sea-water sample from a pearloyster culture pond in the HKUST-CAS Joint Laboratory in Sanya City, Hainan Province, China, on 6 January 2001. Based on polyphasic taxonomy, we propose that strain UST010306-043 ${ }^{\mathrm{T}}$ represents a novel species, Marinomonas ostreistagni sp. nov.

The GenBank/EMBL/DDBJ accession number for the 16S rRNA gene sequence of strain UST010306-043 ${ }^{\top}$ is AB242868.

A figure showing a slot-blot DNA-DNA hybridization assay with DNA of strain UST010306-043 ${ }^{\top}$ as the probe is available as supplementary material in IJSEM Online.
Sanya City is located at the southern tip of Hainan Island $\left(18^{\circ} \mathrm{N} 109^{\circ} \mathrm{E}\right)$, with a tropical oceanic monsoon climate. About $500 \mathrm{ml}$ sea water was sampled from the pearl-oyster culture pond at a depth of $3 \mathrm{~m}$, and was transported in a sterile plastic container to the laboratory within $2 \mathrm{~h}$.

The sea water was filtered through a $1 \mu \mathrm{m}$ polycarbonate filter (Osmonics). Aliquots of $100 \mu$ filtrate were spread on nutrient agar (Oxoid; prepared with $0.45 \mu \mathrm{m}$-filtered sea water) and incubated at room temperature for 2-3 days and then stored at $4{ }^{\circ} \mathrm{C}$. Colonies were purified by being repeatedly restreaked on marine agar 2216 (MA; Difco) plates. Purified strains were stored at $-80{ }^{\circ} \mathrm{C}$ in marine broth $2216(\mathrm{MB})$ with $30 \%$ (v/v) glycerol. Partial 16S rRNA genes were amplified by using the primers GM5F ( $5^{\prime}$-CCTACGGGAGGCAGCAG-3') and 907R (5'-CCGTCAATTCCTTTRAGTTT-3') (Muyzer et al., 1995) with Taq polymerase (Promega) and sequenced using ABI PRISM BigDye Terminator cycle sequencing ready reaction kit version 2.0 and the primer $341 \mathrm{~F}$. Strain UST010306- $043^{\mathrm{T}}$, a single novel isolate related to the genus Marinomonas, was selected for further analysis. Colony morphology was observed after incubation for $24 \mathrm{~h}$ at $30^{\circ} \mathrm{C}$. The temperature range for growth was evaluated in $\mathrm{MB}$ at $4,16,20,25,30,33,37,40$ and $42{ }^{\circ} \mathrm{C}$. Growth at $\mathrm{pH} 3 \cdot 0,4 \cdot 0,5 \cdot 0,6 \cdot 0,7 \cdot 0,8 \cdot 0,9 \cdot 0$ and $10 \cdot 0$ was evaluated in YP-SW broth $(0 \cdot 4 \%$ yeast extract, $0.2 \%$ peptone, $75 \% 0.45 \mu \mathrm{m}$-filtered sea water), adjusted with $1 \mathrm{M} \mathrm{HCl}$ or $\mathrm{NaOH}$. The requirement for sodium ions 
was tested in artificial sea water (ASW; $0 \cdot 1 \% \mathrm{CaCl}_{2} \cdot 2 \mathrm{H}_{2} \mathrm{O}$, $0 \cdot 1 \% \mathrm{KCl}, 0 \cdot 5 \% \mathrm{MgSO}_{4} \cdot 7 \mathrm{H}_{2} \mathrm{O}, 2 \cdot 5 \% \mathrm{NaCl}$ ) (Lewin \& Lounsbery, 1969), with $\mathrm{NaCl}$ replaced by equal molar $\mathrm{KCl}$ and addition of $0 \cdot 4 \%$ yeast extract. Tolerance to $\mathrm{NaCl}$ was tested in ASW supplemented with $0.4 \%$ yeast extract and with $\mathrm{NaCl}$ added at final concentrations of $0,1,2,3,4,5,7 \cdot 5$, 10 and $15 \%$. Anaerobic growth was examined by using the Oxoid anaerobic system for cultures grown on MA supplemented with $0 \cdot 1 \%$ sodium nitrate or $0 \cdot 1 \%$ glucose. Cellular morphology was determined from a MB overnight culture using a Zeiss MC100 Spot microscope at a magnification of $\times 1000$. Flagella morphology was examined by using transmission electron microscopy (JOEL 100CXII at $80 \mathrm{kV}$ ), using cells placed on a carbon grid and stained with $1 \%$ $(\mathrm{w} / \mathrm{v})$ phosphotungstic acid $(\mathrm{pH} 7 \cdot 0)$.

Gram staining was performed according to Collins et al. (1989). Tests for requirement of organic growth factors, utilization of various carbon sources and chitin, fermentation of glucose, sucrose or D-mannitol and accumulation of poly- $\beta$-hydroxybutyrate were performed according to Baumann \& Baumann (1981). Alkaline phosphatase activity, $\mathrm{H}_{2} \mathrm{~S}$ generation from cysteine or thiosulfate, oxidation of glucose and hydrolysis of starch, casein, gelatin and cellulose were determined according to Smibert \& Krieg (1994). Fatty acid methyl ester analysis was performed as described by Svetashev et al. (1995), except that the bacterial strains were cultured at $30^{\circ} \mathrm{C}$ for $24 \mathrm{~h}$. DNA hydrolysis test and sequencing of the nearly complete16S rRNA gene were performed as described by Lau et al. (2005). Related sequences were identified by MEGABLAST search (Zhang et al., 2000), retrieved from the NCBI nucleotide database, aligned using CLUSTAL_X (Thompson et al., 1997), edited with BioEdit version 5.0.9 (Hall, 1999) and analysed using MEGA version 2.1 (Kumar et al., 2001). A phylogenetic tree was generated by using the neighbour-joining method (Saitou \& Nei, 1987) with the Jukes-Cantor substitution model (Jukes \& Cantor, 1969) and was evaluated by bootstrap analysis (Felsenstein, 1985) based on 1000 resamplings. M. aquimarina CECT $5080^{\mathrm{T}}$ and M. communis CECT $5003^{\mathrm{T}}$ were obtained from the Spanish Type Culture Collection.

For DNA-DNA hybridization experiments, genomic DNA was extracted according to Maloy (1990) with modifications: $1.5 \mathrm{ml}$ overnight culture was centrifuged and resuspended in $467 \mu \mathrm{l}$ TE buffer, containing $30 \mu \mathrm{l}$ SDS (10\%, $\mathrm{w} / \mathrm{v})$ and $3 \mu \mathrm{l}$ proteinase $\mathrm{K}\left(20 \mathrm{mg} \mathrm{ml}^{-1}\right)$, incubated at $37^{\circ} \mathrm{C}$ for $1 \mathrm{~h}$ and then extracted twice with equal amounts of phenol/chloroform/isoamyl alcohol (25:24:1, by vol.). DNA was precipitated with $0 \cdot 1$ vol. $3 \mathrm{M}$ sodium acetate ( $\mathrm{pH} 5.2$ ) and $0.6 \mathrm{vol}$. 2-propanol. The precipitate was washed with $0.5 \mathrm{ml} 70 \%$ ethanol, dried in a vacuum, dissolved in $100 \mu \mathrm{l} \mathrm{TE}$ buffer with RNase $\left(100 \mu \mathrm{g} \mathrm{ml}^{-1}\right)$ and incubated at $37^{\circ} \mathrm{C}$ for $1 \mathrm{~h}$. DNA was diluted in TE buffer to $0 \cdot 5-1 \cdot 0 \mathrm{ng} \mu \mathrm{l}^{-1}$ and run in an agarose gel $(1 \%)$ with a $\lambda$ HindIII marker (100 ng; TaKaRa). Quantification of DNA was done by comparing the band intensities of isolated DNA and that of the marker using the Spot Denso function of the
IS-1000 Digital Imaging System (Alpha Innotech). Slot-blot analysis of DNA was performed according to Brown (2005) with Hybond-N + membrane (Millipore). One or $10 \mathrm{ng}$ genomic DNA of each strain was loaded per well. One hundred nanogram probe DNA was labelled using the Gene Image random prime labelling module (Amersham), according to the manufacturer's instructions. Overnight hybridization was performed at $60^{\circ} \mathrm{C}$. The membrane was washed three times with $1 \times \mathrm{SSC} / 0 \cdot 1 \% \mathrm{SDS}$ and three times with $0 \cdot 5 \times \mathrm{SSC} / 0 \cdot 1 \% \mathrm{SDS}$ at $60^{\circ} \mathrm{C}$ (each washing step lasted for $10 \mathrm{~min}$ ), detected using a Gene Image CDP-Star detection module (Amersham) according to the manufacturer's instructions and exposed to a 100NIF Xray film (Fuji) for $15 \mathrm{~min}$. Levels of hybridization were determined with EagleSight software version 3.2 in the Eagle Eye II system (Stratagene). The DNA G $+\mathrm{C}$ content was determined by using the HPLC method (Mesbah et al., 1989), with genomic DNA extracted with a MiniBEST Bacterial Genomic DNA Extraction kit (TaKaRa). Susceptibility to antibiotics was tested by using the disc-diffusion plate method on MA. The following antibiotics were tested: ampicillin $(10 \mu \mathrm{g})$, polymyxin B (300 U), chloramphenicol $(30 \mu \mathrm{g})$, tetracycline $(30 \mu \mathrm{g})$, streptomycin $(10 \mu \mathrm{g})$, rifampicin $(10 \mu \mathrm{g})$ and penicillin $\mathrm{G}(2 \mathrm{U})$.

Table 1. Whole-cell fatty acid profiles of strain UST010306-043 ${ }^{\top}$ and related members of the genus Marinomonas

Strains: 1, UST010306-043 ${ }^{\mathrm{T}}$; 2, M. aquimarina CECT 5080 $; 3$, M. communis CECT $5003^{\mathrm{T}}$. Data from this study. Values are percentages of total fatty acids. Fatty acids are designated as follows: total number of carbon atoms: number of double bonds, followed by the position of the double bond from the aliphatic end of the molecule. ECL, equivalent chain-length.

\begin{tabular}{|lrrr|}
\hline Fatty acid & $\mathbf{1}$ & $\mathbf{2}$ & $\mathbf{3}$ \\
\hline Straight-chain fatty acids: & & & \\
$10: 0$ & $5 \cdot 4$ & $5 \cdot 2$ & $3 \cdot 2$ \\
$12: 0$ & $5 \cdot 7$ & $5 \cdot 0$ & $5 \cdot 4$ \\
$14: 0$ & $4 \cdot 2$ & $3 \cdot 0$ & $3 \cdot 0$ \\
$16: 0$ & $15 \cdot 6$ & $13 \cdot 0$ & $10 \cdot 4$ \\
$18: 0$ & $1 \cdot 14$ & $1 \cdot 3$ & $1 \cdot 4$ \\
Unsaturated fatty acids: & & & \\
$15: 1 \omega 8 c$ & $0 \cdot 0$ & $0 \cdot 0$ & $0 \cdot 2$ \\
$18: 1 \omega 7 c$ & $39 \cdot 5$ & $40 \cdot 4$ & $41 \cdot 8$ \\
Hydroxy fatty acids: & & & \\
$10: 0$ 3-OH & $7 \cdot 8$ & $9 \cdot 2$ & $10 \cdot 5$ \\
$12: 0$ 3-OH & $0 \cdot 0$ & $0 \cdot 2$ & $0 \cdot 0$ \\
Summed features: & & & \\
1 & $19 \cdot 7$ & $22 \cdot 4$ & $24 \cdot 0$ \\
2 & $1 \cdot 0$ & $0 \cdot 2$ & $0 \cdot 0$ \\
Unknown ECL $11 \cdot 799$ & $0 \cdot 0$ & $0 \cdot 1$ & $0 \cdot 0$ \\
\end{tabular}

${ }^{\star} 1,16: 1 \omega 7 c / 15: 0$ iso $2-\mathrm{OH} ; 2,19: 1 \omega 6 c / 19: 0$ cyclo/unknown ECL $18 \cdot 846$. 
Table 2. Characteristics that differentiate strain UST010306- $043^{\top}$ from other members of the genus Marinomonas

Taxa: 1, strain UST010306-043 ${ }^{\mathrm{T}}$; 2, M. aquimarina (data from Macián et al., 2005); 3, M. communis (Baumann et al., 1972); 4, M. vaga (Baumann et al., 1972); 5, M. pontica 46-16 ${ }^{\mathrm{T}}$ (Ivanova et al., 2005); 6, M. dokdonensis (Yoon et al., 2005); 7, M. mediterranea MMB-1 ${ }^{\mathrm{T}}$ (Solano et al., 1997; Solano \& Sanchez-Amat, 1999); 8, M. primoryensis IAM 15010 ${ }^{\mathrm{T}}$ (Romanenko et al., 2003); 9, M. ushuaiensis U1 ${ }^{\mathrm{T}}$ (Prabagaran et al., 2005). +, Positive; -, negative; ND, data not available; V, variable; W, weakly positive.

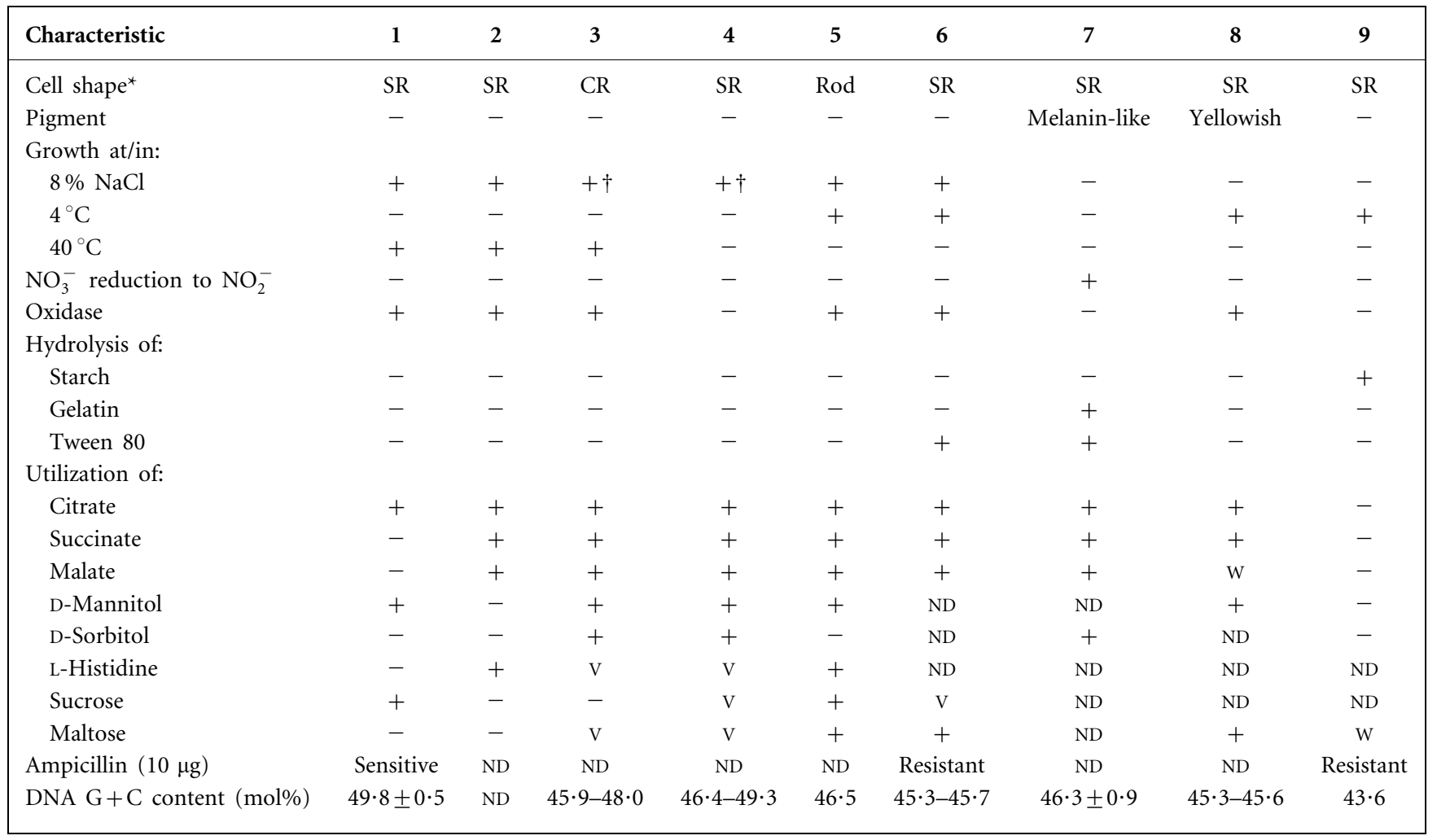

${ }^{\star} \mathrm{CR}$, curved rod; SR, straight rod.

$\dagger$ Data from Ivanova et al. (2005).

Morphological, physiological and biochemical features of UST010306-043 ${ }^{\mathrm{T}}$ are given in the species description.

Strain UST010306-043 ${ }^{\mathrm{T}}$ shared many similarities with other Marinomonas species. Strains were all Gram-negative, isolated from marine habitats, had rod-shaped cells, were halophilic, strictly aerobic, heterotrophic, non-spore-forming and non-fermentative, utilized glucose and acetate and did not require complex organic growth factors. Strain UST010306-043 ${ }^{\mathrm{T}}$ shared many similarities with $M$. aquimarina; in particular, their similarity in habitat (the former was found in sea water of a pearl-oyster pond and the latter was found in oyster flesh and sea water), growth up to $40{ }^{\circ} \mathrm{C}$ but not at $4{ }^{\circ} \mathrm{C}$, oxidative response to glucose and inability to utilize maltose and D-sorbitol. The $\mathrm{G}+\mathrm{C}$ content of the DNA of strain UST010306-043 ${ }^{\mathrm{T}}$ was $49 \cdot 8 \pm 0.5 \mathrm{~mol} \%$, which was close to the highest $\mathrm{G}+\mathrm{C}$ content of members of the genus Marinomonas (Sanchez-Amat \& Solano, 2005). The fatty acids of strain UST010306-043 ${ }^{\mathrm{T}}$ and closely related species are shown in Table 1 . The fatty acid profile of strain UST010306-043 ${ }^{\mathrm{T}}$ was very similar to that of $M$. aquimarina CECT $5080^{\mathrm{T}}$, but differed from that of $M$. communis CECT

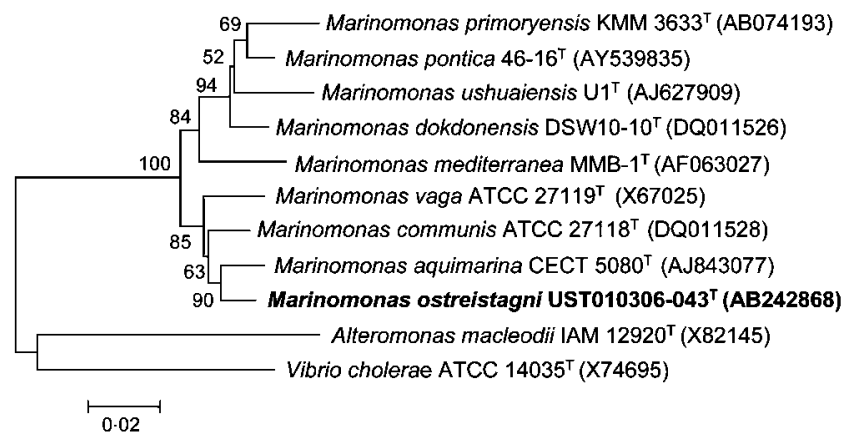

Fig. 1. Phylogenetic relationship of strain UST010306-043 ${ }^{\top}$ and other members of the genus Marinomonas based on 16S rRNA gene sequences. The tree was created using the neighbourjoining method. Numbers at nodes represent percentage bootstrap values from 1000 resampled datasets. Alteromonas macleodii IAM $12920^{\top}$ and Vibrio cholerae ATCC $14035^{\top}$ were used as an outgroup. Bar, 0.02 nucleotide substitutions per position. 
$5003^{\mathrm{T}}$ by having a slightly higher percentage of straightchain fatty acids. Overall, the fatty acid profiles of strain UST010306-043 ${ }^{\mathrm{T}}$ and members of the genus Marinomonas had a similar pattern; namely, with over $60 \%$ fatty acids distributed among $18: 1 \omega 7 c, 16: 0 / 16: 0$ iso and $16: 1 \omega 7 c$ 15:0 iso 2-OH (Table 1; Ivanova et al., 2000, 2005; Yoon et al., 2005; Prabagaran et al., 2005). Characteristics that differentiated strain UST010306-043 ${ }^{\mathrm{T}}$ from other species of Marinomonas are shown in Table 2.

Phylogenetic analysis showed that strain UST010306-043 ${ }^{\mathrm{T}}$ formed a distinct taxon within the genus Marinomonas and was closely linked with M. aquimarina CECT $5080^{\mathrm{T}}$ with a bootstrap value of $90 \%$ (Fig. 1). The $16 \mathrm{~S}$ rRNA gene sequence of strain UST010306-043 ${ }^{\mathrm{T}}$ shared $94 \cdot 1-97 \cdot 7 \%$ similarity with other members of the genus Marinomonas, being most closely related to M. aquimarina $(97 \cdot 5-97 \cdot 7 \%)$ and M. communis $(97 \cdot 1 \%)$. Its similarity to other species of Marinomonas was less than $97 \%$, indicating that they were different species (Stackebrandt \& Goebel, 1994). As the 16S rRNA gene similarity of strain UST010306-043 ${ }^{\mathrm{T}}$ with $M$. aquimarina and $M$. communis was at the borderline for discrimination of species by sequence analysis (Stackebrandt \& Goebel, 1994), DNA-DNA hybridization, which has significantly higher resolution power than sequence analysis (Amann et al., 1992), was performed. The results of DNADNA hybridization (available as Supplementary Fig. S1 in IJSEM Online) showed that the levels of relatedness of strain UST010306-043 ${ }^{\mathrm{T}}$ with M. aquimarina CECT $5080^{\mathrm{T}}$ and $M$. communis CECT $5003^{\mathrm{T}}$ were below $23 \%$. This was well below the $70 \%$ threshold value for species discrimination (Wayne et al., 1987), suggesting that strain UST010306-043 ${ }^{\mathrm{T}}$ represents a species that is different from M. aquimarina or M. communis. On the basis of all characteristics described above, a novel species with the name Marinomonas ostreistagni sp. nov. is proposed.

\section{Description of Marinomonas ostreistagni sp. nov.}

Marinomonas ostreistagni (os.tre'i.stag' ni. L. fem. n. ostrea oyster; L. gen. neut. n. stagni of/from a pond; N.L. gen. neut. n. ostreistagni from/of oyster pond).

Cells are Gram-negative rods, $0 \cdot 6-3 \cdot 6 \mu \mathrm{m}$ in length and $0.4-0.6 \mu \mathrm{m}$ in diameter and motile by a single polar flagellum. Cells divide by binary fission. Heterotrophic, strictly aerobic and requires sodium ions for growth. Cell aggregates are detected when cultured in MB. Colonies are non-pigmented, circular, opaque, convex, $1-2 \mathrm{~mm}$ in diameter with an entire margin after $24 \mathrm{~h}$ incubation at $30{ }^{\circ} \mathrm{C}$ on MA. Grows in $1-10 \% \mathrm{NaCl}$ but not in $15 \% \mathrm{NaCl}$; optimum $\mathrm{NaCl}$ for growth is approximately $3 \%$. Grows at $16-40{ }^{\circ} \mathrm{C}$, but not at 4 or $42^{\circ} \mathrm{C}$; optimum temperature for growth is $33-37^{\circ} \mathrm{C}$. Grows at $\mathrm{pH} 5 \cdot 0-9 \cdot 0$, with optimum growth occurring around $\mathrm{pH} 7 \cdot 0$. Oxidase-, catalase- and alkaline phosphatase-positive. Oxidizes glucose. Does not produce sulfide from cysteine or thiosulfate and does not degrade extracellular DNA. Does not form endospores and does not accumulate poly- $\beta$-hydroxybutyrate. Utilizes glucose, sucrose, D-mannitol, aesculin, L-alanine, L-asparagine, L-serine, L-glutamic acid, acetate, citrate, pyruvate, propionate, lactate, ethanol and Tween 20, but not galactose, maltose, L-arabinose, trehalose, rhamnose, lactose, melibiose, D-sorbitol, methanol, glycerol, succinate, malate, glycine, L-leucine, L-arginine, L-lysine, L-histidine, Lmethionine, L-threonine, valine, starch, gelatin, casein, agar, DNA, Tween 40, Tween 60, Tween 80 or cellulose. Does not ferment glucose, sucrose or D-mannitol. Sensitive to ampicillin $(10 \mu \mathrm{g})$, polymyxin B (300 $\mathrm{U})$, chloramphenicol $(30 \mu \mathrm{g})$, tetracycline $(30 \mu \mathrm{g})$, streptomycin $(10 \mu \mathrm{g})$ and rifampicin $(10 \mu \mathrm{g})$, but resistant to penicillin $\mathrm{G}(2 \mathrm{U})$. Predominant fatty acids are $18: 1 \omega 7 c, 16: 0$ and $16: 1 \omega 7 c /$ $15: 0$ iso $2-\mathrm{OH}$. The DNA G $+\mathrm{C}$ content is $49 \cdot 8 \pm 0 \cdot 5 \mathrm{~mol} \%$.

The type strain is UST010306-043 ${ }^{\mathrm{T}}\left(=\mathrm{JCM} 13672^{\mathrm{T}}=\mathrm{NRRL}\right.$ $\mathrm{B}-41433^{\mathrm{T}}$ ), which was isolated from the pearl-oyster culture pond of HKUST-CAS Joint Laboratory, Sanya, Hainan Province, China.

\section{Acknowledgements}

We sincerely thank Professor Dr Hans G. Trüper for valuable suggestions for the etymology, Mr Tze Kin Cheung for transmission electron microscopy analysis and Dr Xiancui Li for DNA G + C content analysis. This work was supported by grants R5498, CMI03/04.SC03, CAs-CF03/04.Sc01 and CA04/05.SC01.

\section{References}

Amann, R. I., Lin, C., Key, R., Montgomery, L. \& Stahl, D. A. (1992). Diversity among Fibrobacter strains: towards a phylogenetic classification. Syst Appl Microbiol 15, 23-31.

Baumann, P. \& Baumann, L. (1981). The marine gram-negative eubacteria: genera Photobacterium, Beneckea, Alteromonas, Pseudomonas and Alcaligenes. In The Prokaryotes, vol. 1, pp. 1302-1331. Edited by M. P. Starr, H. Stolp, H. G. Trüper, A. Balows \& H. Schlegel. Berlin: Springer.

Baumann, L., Baumann, P., Mandel, M. \& Allen, R. D. (1972). Taxonomy of aerobic marine eubacteria. J Bacteriol 3, 402-429.

Brown, T. (2005). Dot and slot blotting of DNA onto a positively charged nylon membrane using a manifold. In Current Protocols in Molecular Biology, pp. 2.9.18-2.9.20. Edited by F. M. Ausubel, R. Brent, R. E. Kingston, D. D. Moore, J. G. Seidman, J. A. Smith \& K. Struhl. New York: Wiley.

Collins, C. H., Lyne, P. M. \& Grange, J. M. (1989). Collins and Lyne's Microbiological Methods. London: Butterworth.

Felsenstein, J. (1985). Confidence limits on phylogenies: an approach using the bootstrap. Evolution 39, 783-791.

Hall, T. A. (1999). BioEdit: a user-friendly biological sequence alignment editor and analysis program for Windows 95/98/NT. Nucleic Acids Symp Ser 41, 95-98.

Ivanova, E. P., Zhukova, N. V., Svetashev, V. I., Gorshkova, N. M., Kurilenko, V. V., Frolova, G. M. \& Mikhailov, V. V. (2000). Evaluation of phospholipid and fatty acid compositions as chemotaxonomic markers of Alteromonas-like proteobacteria. Curr Microbiol 41, 341-345.

Ivanova, E. P., Onyshchenko, O. M., Christen, R., Lysenko, A. M., Zhukova, N. V., Shevchenko, L. S. \& Kiprianova, E. A. (2005). Marinomonas pontica sp. nov., isolated from the Black Sea. Int J Syst Evol Microbiol 55, 275-279. 
Jukes, T. H. \& Cantor, C. R. (1969). Evolution of protein molecules. In Mammalian Protein Metabolism, pp. 21-132. Edited by $\mathrm{H}$. N. Munro. New York: Academic Press.

Kumar, S., Tamura, K., Jakobsen, I. B. \& Nei, M. (2001). MEGA2: molecular evolutionary genetics analysis software. Bioinformatics 17, $1244-1245$.

Lau, K. W. K., Ng, C. Y. M., Ren, J., Lau, S. C. L., Qian, P.-Y., Wong, P.-K., Lau, T. C. \& Wu, M. (2005). Owenweeksia hongkongensis gen. nov., sp. nov., a novel marine bacterium of the phylum 'Bacteroidetes'. Int J Syst Evol Microbiol 55, 1051-1057.

Lewin, R. A. \& Lounsbery, D. M. (1969). Isolation, cultivation and characterization of flexibacteria. J Gen Microbiol 58, 145-170.

Macián, M. C., Arahal, D. R., Garay, E. \& Pujalte, M. J. (2005). Marinomonas aquamarina sp. nov., isolated from oysters and seawater. Syst Appl Microbiol 28, 145-150.

Maloy, S. R. (1990). Experimental Techniques in Bacterial Genetics. Boston: Jones and Bartlett.

Mesbah, M., Premachandran, U. \& Whitman, W. B. (1989). Precise measurement of the $\mathrm{G}+\mathrm{C}$ content of deoxyribonucleic acid by highperformance liquid chromatography. Int J Syst Bacteriol 39, 159-167.

Muyzer, G., Teske, A., Wirsen, C. O. \& Jannasch, H. W. (1995). Phylogenetic relationships of Thiomicrospira species and their identification in deep-sea hydrothermal vent samples by denaturing gradient gel electrophoresis of $16 \mathrm{~S}$ rDNA fragments. Arch Microbiol 164, 165-172.

Prabagaran, S. R., Suresh, K., Manorama, R., Delille, D. \& Shivaji, S. (2005). Marinomonas ushuaiensis sp. nov., isolated from coastal sea water in Ushuaia, Argentina, sub-Antarctica. Int J Syst Evol Microbiol 55, 309-313.

Romanenko, L. A., Uchino, M., Mikhailov, V. V., Zhukova, N. V. \& Uchimura, T. (2003). Marinomonas primoryensis sp. nov., a novel psychrophile isolated from coastal sea-ice in the Sea of Japan. Int $J$ Syst Evol Microbiol 53, 829-832.

Saitou, N. \& Nei, M. (1987). The neighbor-joining method: a new method for reconstructing phylogenetic trees. Mol Biol Evol 4, 406-425.

Sanchez-Amat, A. \& Solano, F. (2005). Genus III. Marinomonas Van Landschoot and De Ley 1984, 91 ${ }^{\mathrm{VP}}$ (effective publication: Van
Landschoot and De Ley 1983, 3071). In Bergey's Manual of Systematic Bacteriology, vol. 2, part B, pp. 284-289. Edited by D. J. Brenner, N. R. Krieg \& J. T. Staley. New York: Springer.

Smibert, R. M. \& Krieg, N. R. (1994). Phenotypic characterization. In Methods for General and Molecular Bacteriology, pp. 607-654. Edited by P. Gerhardt, R. G. E. Murray, W. A. Wood \& N. R. Krieg. Washington, DC: American Society for Microbiology.

Solano, F. \& Sanchez-Amat, A. (1999). Studies on the phylogenetic relationships of melanogenic marine bacteria: proposal of Marinomonas mediterranea sp. nov. Int J Syst Bacteriol 49, 1241-6.

Solano, F., García, E., Perez De Egea, E. \& Sanchez-Amat, A. (1997). Isolation and characterization of strain MMB-1 (CECT 4803), a novel melanogenic marine bacterium. Appl Environ Microbiol 63, 3499-3506.

Stackebrandt, E. \& Goebel, B. M. (1994). Taxonomic note: a place for DNA-DNA reassociation and 16S rRNA sequence analysis in the present species definition in bacteriology. Int J Syst Bacteriol 44, 846-849.

Svetashev, V. I., Vysotskii, M. V., Ivanova, E. P. \& Mikhailov, V. V. (1995). Cellular fatty acids of Alteromonas species. Syst Appl Microbiol 18, 37-43.

Thompson, J. D., Gibson, T. J., Plewniak, F., Jeanmougin, F. \& Higgins, D. G. (1997). The CLUSTAL_X windows interface: flexible strategies for multiple sequence alignment aided by quality analysis tools. Nucleic Acids Res 25, 4876-4882.

Van Landschoot, A. \& De Ley, J. (1983). Intra- and intergeneric similarities of the rRNA cistrons of Alteromonas, Marinomonas (gen. nov.) and some other Gram-negative bacteria. J Gen Microbiol 129, 3057-3074.

Wayne, L. G., Brenner, D. J., Colwell, R. R. \& 9 other authors (1987). International Committee on Systematic Bacteriology. Report of the ad hoc committee on reconciliation of approaches to bacterial systematics. Int J Syst Bacteriol 37, 463-464.

Yoon, J.-H., Kang, S.-J. \& Oh, T.-K. (2005). Marinomonas dokdonensis sp. nov., isolated from sea water. Int J Syst Evol Microbiol 55, 2303-2307.

Zhang, Z., Schwartz, S., Wagner, L. \& Miller, W. (2000). A greedy algorithm for aligning DNA sequences. J Comput Biol 7, 203-214. 